DOEIEM-0265

\title{
Uranium Enrichment Decontamination and Decommissioning Fund
}

\section{Report}
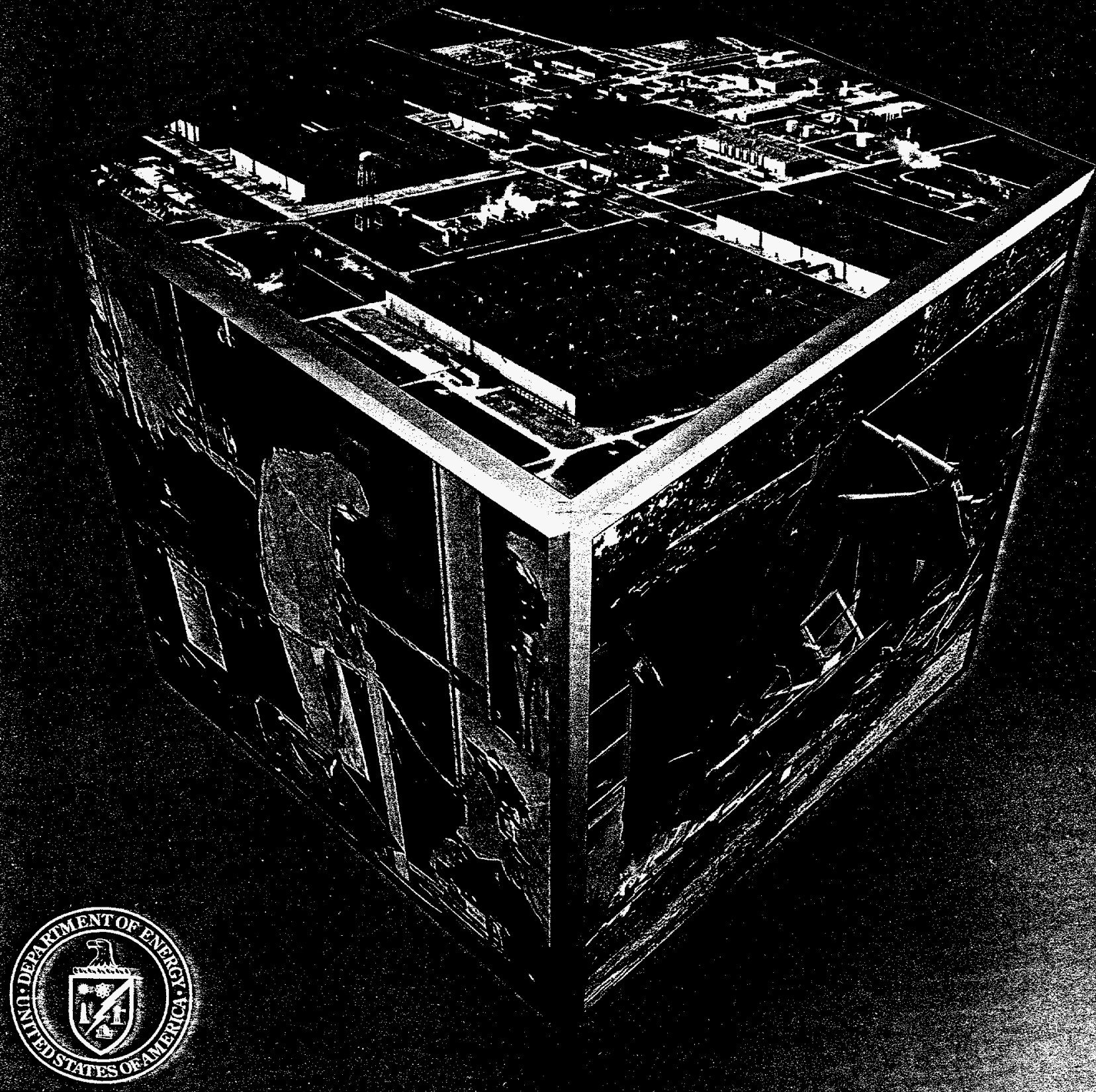

U.S. Bepantment of Energy

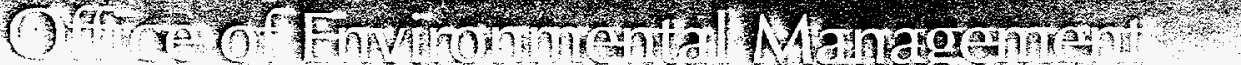


Available to DOE and DOE contractors from the Office of Scientific and Technical Information, P.O. Box 62, Oak Ridge, TN 37831; prices available from (615) 576-8401.

Available to the public from the National Technical Information Service, U.S. Department of Commerce, 5285 Port Royal Rd., Springfield, VA 22161.

Cover Photographs: One of the three gaseous diffusion plants owned by the United States Department of Energy, and examples of environmental restoration work performed at these sites.

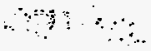


Uranium Enrichment

Decontamination and

Decommissioning Fund

1994 Report

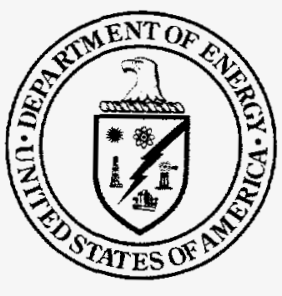

DISTRIBUTION OF THIS DOCUMENT IS UNLIMITED.

U.S. Department of Energy

Office of Environmental Management Washington, D.C. 20585 


\section{DISCLAMIER}

Portions of this document may be illegible in electronic image products. Images are produced from the best available original document. 
ne of the most challenging issues facing the Department of Energy's Office of Environmental Management is the cleanup of the Department's three gaseous diffusion plants: a shutdown facility in Oak Ridge, Tennessee; and two operating facilities in Paducah, Kentucky, and Portsmouth, Ohio. Technical and stakeholder hurdles are substantial, and the magnitude of the task is daunting. The facilities include:

$\cong 30$ million square feet of floor space - the size of 550 football fields,

$\equiv 400$ million cubic feet of space - the equivalent of four World Trade Centers,

高 10,000 converter vessels used in the gaseous diffusion process - each the size of a delivery truck,

䇊 10,000 compressors and pumps, and

miles of interconnecting piping and electrical cable.

The gaseous diffusion facilities were built in the 1940s and 1950s to provide enriched uranium for defense purposes. In the late 1950s and early 1960s, as the Government began to explore peaceful uses for nuclear energy, the mission of the gaseous diffusion plants was expanded to provide enriched uranium for commercial nuclear power plants. The gaseous diffusion facility in Oak Ridge was shut down in 1987. Today, the two operating gaseous diffusion plants provide enrichment services only to the commercial power industry.

As the gaseous diffusion plants approach the end of their useful lives, our challenge is to safely decontaminate and decommission them for future use. In October 1992, Congress passed the Energy Policy Act of 1992 and established the Uranium Enrichment Decontamination and Decommissioning Fund to accomplish this task.

We approach this mission as responsible stewards of the environment, while undertaking this mission in a financially responsible way by:

吾 devising cost-effective technical solutions;

立 producing realistic life-cycle cost estimates, based on practical assumptions and thorough analysis;

吾 generating coherent long-term plans which are based on risk assessments, land use, and input from stakeholders; and

琹 showing near-term progress in the cleanup of the gaseous diffusion facilities at Oak Ridge.

The Department of Energy is committed to decommissioning the gaseous diffusion plants in a safe, environmentally responsible, and cost effective manner. We welcome your ideas on accomplishing this task.
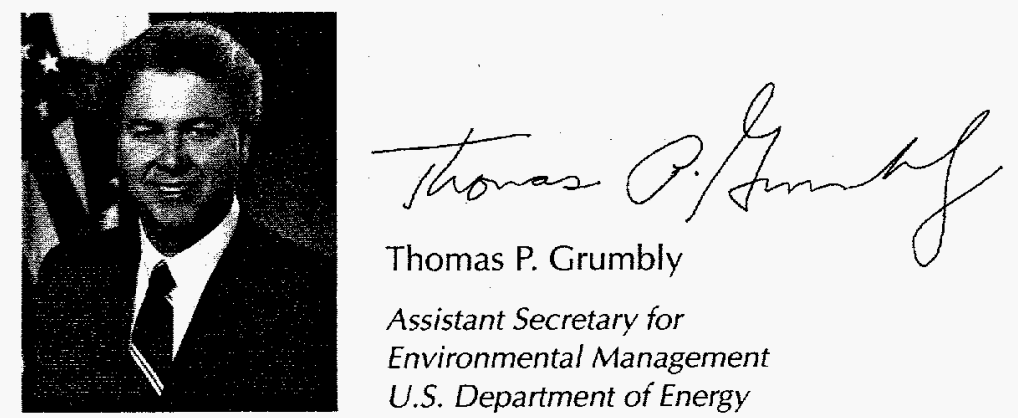

Assistant Secretary for Environmental Management U.S. Department of Energy 



\section{Contents}

Origin and Management

of the

D\&D Fund . . . . . . . . 1

Managing

the Work ........... 3

Reducing the

Costs of

Decommissioning . . . 11

Financial

Reports........... 15

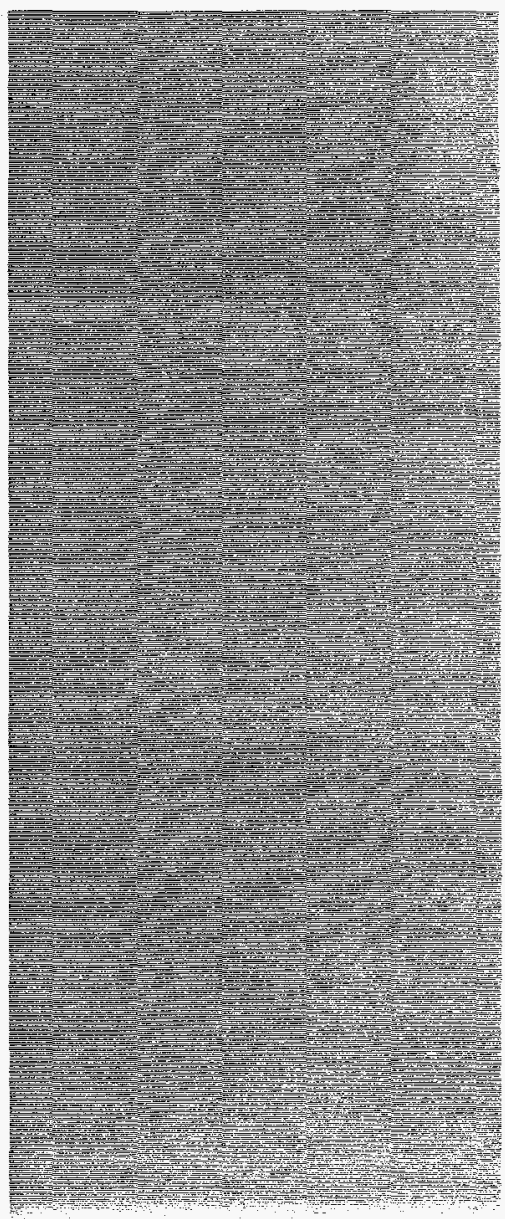




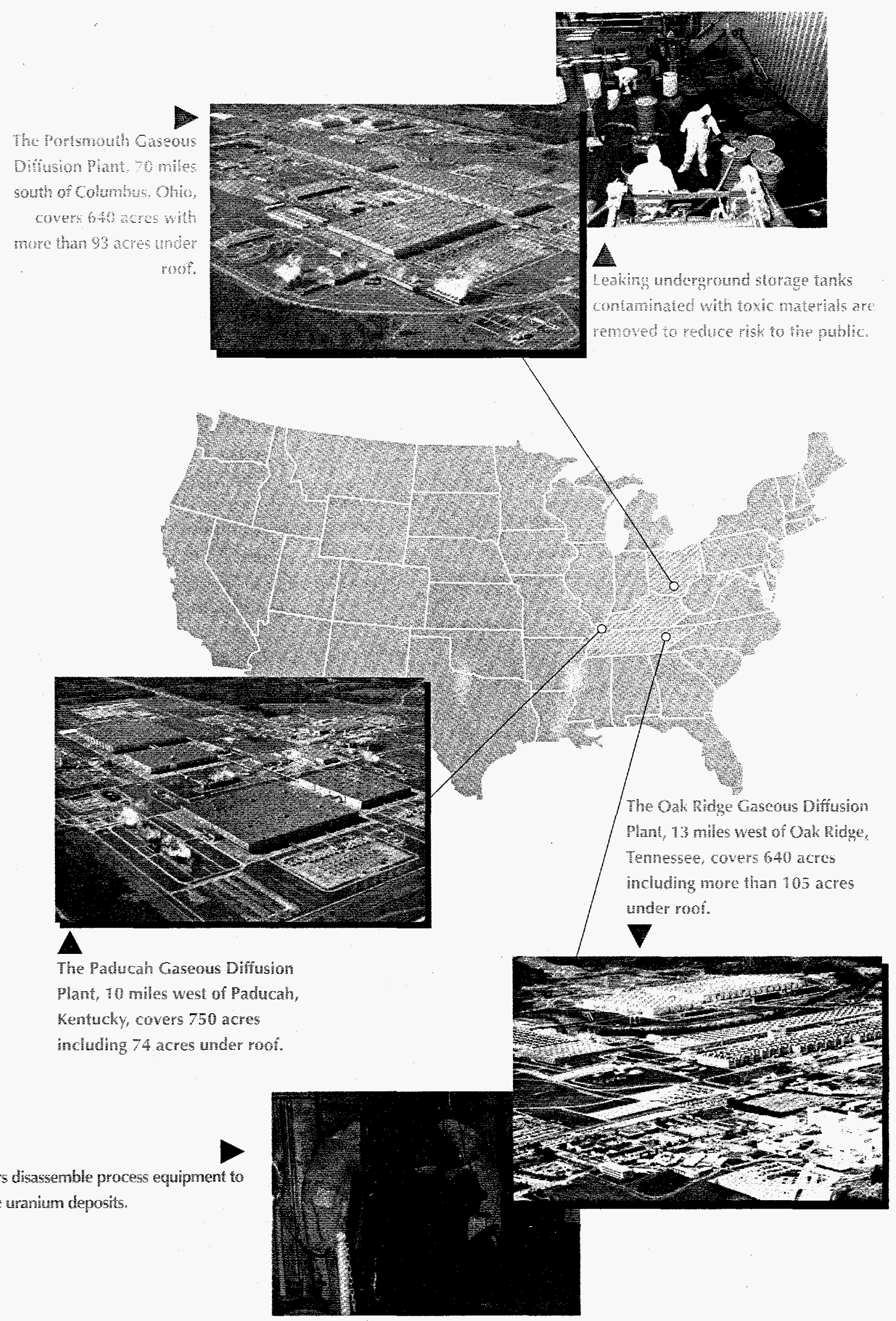




\section{Origin and Management of the D\&D Fund}

History leading to the

Decontamination and

Decommissioning (D\&D) Fund

n 1945, the United States

Atomic Energy Commission

(AEC) completed the first

L. gaseous diffusion plant

(GDP) in Oak Ridge, Tennessee.

This plant produced enriched uranium for nuclear weapons.

Construction of two additional

facilities in Paducah, Kentucky,

and Portsmouth, Ohio, began in

1951 and 1952, respectively. In

the late 1950 s and early 1960 s,

the Federal Government began

promoting peaceful uses for

nuclear energy. Laws were

changed to permit private

ownership of nuclear materials,

paving the way for construction

of nuclear power plants. The

Government-owned GDPs

provide a vital link in the fuel

supply chain for commercial

nuclear power operations;

today, the GDPs' sole customer

is the commercial power

industry.
Production at the Oak Ridge

enrichment facility ceased in

1985, and the Government shut

down the plant permanently in

1987. The Energy Policy Act of

1992 ("the Act") transferred

uranium enrichment activities at

the two remaining plants to the

United States Enrichment

Corporation (USEC) on July 1 , 1993. The USEC is currently

leasing the Paducah and

Portsmouth GDPs from the

Department of Energy (DOE).

However, the Act requires DOE

to retain ownership and respon-

sibility for the costs of environ-

mental cleanup resulting from

the Government's past operation of all three gaseous diffusion

facilities. Prior to transferring the operating uranium enrichment facilities to the USEC, DOE conducted an environmental audit of the GDPs, which identified existing environmental conditions that remain DOE's responsibility.
DOE must perform certain

preliminary activities, such as

removal of hazardous materials, D\&D engineering design, and permitting of $D \& D$ activities, before $D \& D$ can begin at the three sites. These preliminary activities began in Fiscal Year 1988 at the Oak Ridge Gaseous Diffusion Plant (ORGDP). Decommissioning of the Oak Ridge Gaseous Diffusion Plant is currently scheduled to begin in Fiscal Year 2002, although DOE has already demolished and is in the process of demolishing some peripheral structures. DOE will initiate $D \& D$ activities at the Paducah and Portsmouth facilities after the USEC ceases uranium enrichment operations at the GDPs and transfers these facilities back to the DOE under the terms and conditions of the lease. 


\section{D\&D Fund established to finance cleanup activities}

To finance environmental restoration at gaseous diffusion facilities, the Act established the Uranium Enrichment Decontamination and Decommissioning Fund (D\&D Fund). Specifically, the $D \& D$ Fund is designed to:

- pay for the costs of decontamination and decommissioning activities for the gaseous diffusion facilities;

- pay the annual costs for remedial action at the diffusion facilities to the extent that the amount in the D\&D Fund is sufficient; and

- reimburse active uranium/ thorium processing sites licensed under the Atomic Energy Act of 1954 for up to $\$ 310$ million (adjusted for inflation) for environmental cleanup costs incident to. sales to the Federal Government.

\section{Sound financial management is a cornerstone of the D\&D Fund}

The Act authorizes contributions to the D\&D Fund of $\$ 480$ million per year (adjusted for inflation) for 15 years. These contributions come from two sources: an assessment on domestic utilities of up to $\$ 150$ million annually, and Federal Government appropriations for the difference between $\$ 480$ million and the utility assessment. The utility collections will continue for 15 years from the date of enactment of the Energy Policy Act (1992) or until $\$ 2.25$ billion (adjusted for inflation) has been collected.

The special assessment is based upon the amount of uranium enrichment services purchased by domestic utilities from the Federal Government. The D\&D Fund first collected revenues from domestic utilities in Fiscal Year 1993. The first Government contribution was received in Fiscal Year 1994, the same year Congress appropriated expenditures from the D\&D Fund.

Strong internal controls as well as internal and external audits ensure that the $D \& D$ Fund is soundly managed. DOE invests undisbursed fund balances in United States Treasury securities, and interest earned from these investments is returned to the D\&D Fund for future use. The D\&D Fund's investment strategy is to maximize interest earnings for use in cleanup of the GDPs. 


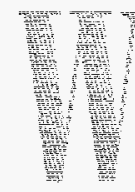

hen the AEC originally

built and began operating the GDPs, it could not anticipate

the technical and management challenges it would face in decontaminating and decommissioning those same facilities 50 years later. "Decontamination" involves the removal or reduction of radioactive or hazardous materials from facilities, equipment, or soils to achieve a stated objective or end condition. That objective may be to reduce exposure to workers, to release the site or material for other use, or to comply with criteria for waste acceptance should disposal be necessary. "Decommissioning" is a broader term that includes decontamination and dismantlement. The ultimate goal of decommissioning may be either unrestricted release or restricted use of the site.

\section{Developing a long-term strategy}

The Department is now developing a long-term strategy to safely and efficiently address the technical and management challenges while performing actions necessary to reduce risk to workers, the public, and the environment in the short-term. The long-term strategic plan that DOE is developing, with input from stakeholders, will identify and evaluate possible approaches to transition the GDP facilities to an inactive status as well as options for decontaminating, decommissioning, and reusing the facilities. Objectives of the strategic planning process include involving regulators and other key stakeholders in decisionmaking, utilizing innovative technologies for D\&D, developing plans and criteria for recycling materials generated during $D \& D$, evaluating land use options, developing a publically-accepted standard for residual radiation, and ensuring efficient use of resources.
While these long-term plans are being established, DOE is taking steps to address immediate risks to workers, the public, and the environment posed by the gaseous diffusion facilities. Examples of work performed at the three GDPs during Fiscal Year 1994 to reduce risk include:

” removal of over 13 miles of asbestos from buildings,

E्土 removal and preparation for off-site shipment of more than 10,000 pieces of electrical equipment contaminated with polychlorinated biphenyls (PCBs), and

= disposal of hundreds of thousands of gallons of PCBcontaining fluids.

\section{Each GDP site is unique}

Each of the three uranium enrichment plants-Oak Ridge, Tennessee; Portsmouth, Ohio; and Paducah, Kentucky--and 


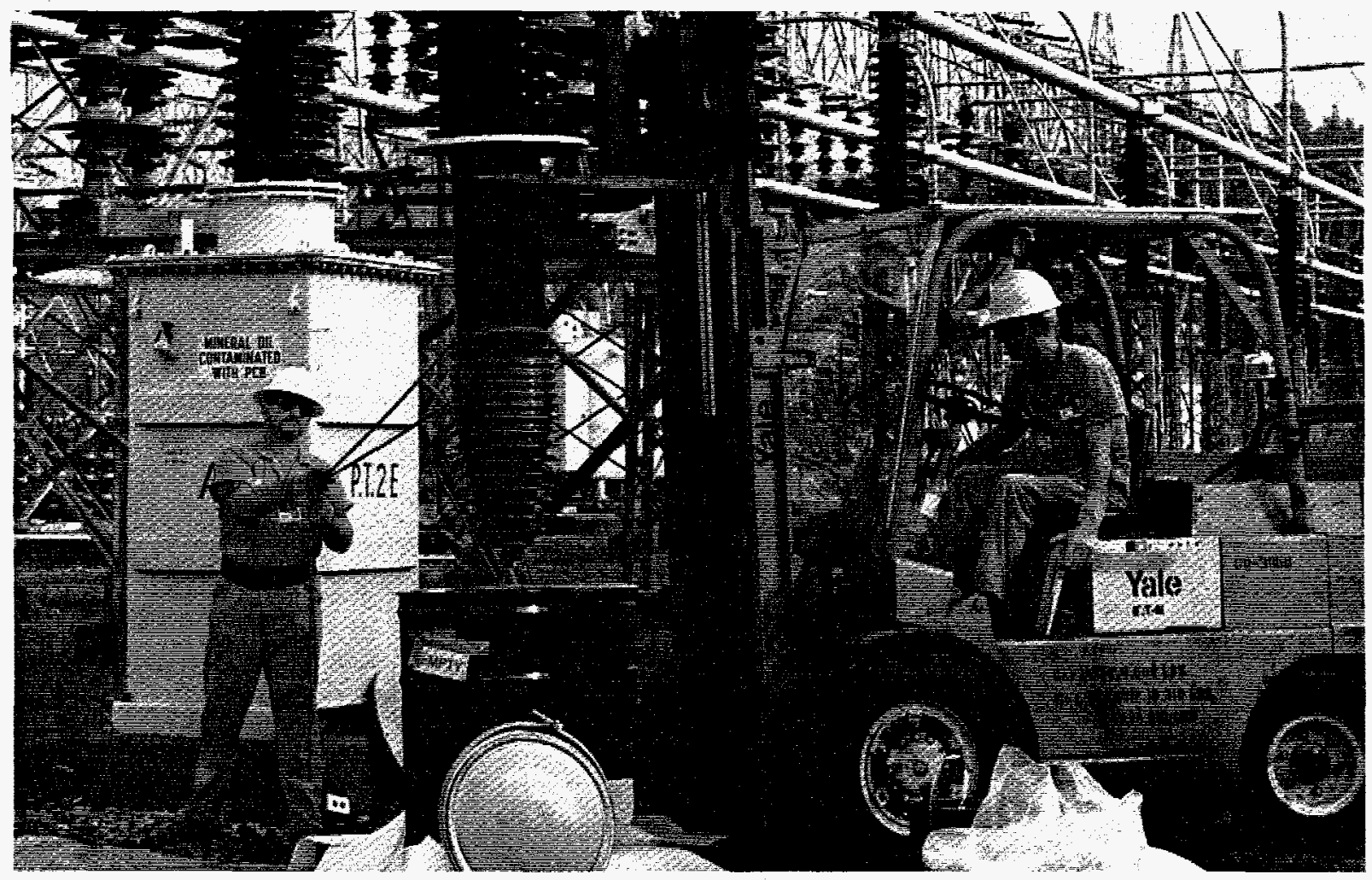

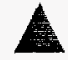

Chin stons

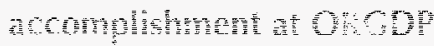

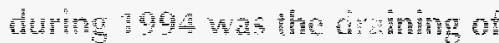

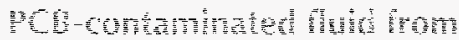
thomands of extrotent

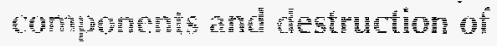
Fin.

their surrounding areas have unique environmental conditions. In addition, the varied locations have a major impact on citizen and state regulator participation in the $D \& D$ decision-making process. DOE will tailor the D\&D approach to the specific conditions at each GDP site while taking advantage of the similarities to reduce overall cost.

The Oak Ridge Gaseous Diffusion Plant was the first gaseous diffusion facility ever built and is located 13 miles west of Oak Ridge, Tennessee. During its 50year history, the plant produced enriched uranium hexaflouride (UF6) for defense purposes and for nuclear power reactors.

When the Government ended production of highly enriched uranium for weapons in 1964, it closed the K-25 and K-27 buildings. Due to declining demand for enriched uranium, the Government put the remainder of the facility in standby status in 1985; ORGDP was permanently shut down in 1987.

The ORGDP's 640 acres contain 340 buildings, some of which are massive. For example, the two wings of the original K-25 Building are each one-half mile long. Typical outdoor areas with contamination at the ORGDP include settling lagoons and drum storage areas, which include both radioactive and hazardous wastes.

The Portsmouth Gaseous Diffusion Plant is located 20 miles north of the city of Portsmouth, Ohio and 70 miles south of Columbus, Ohio. The 640 acre site is located in sparsely populated Pike County in southeastern Ohio. The Portsmouth GDP was completed in 1956 and produced enriched uranium for commercial nuclear power plants, the Navy nuclear fleet, and research reactors. Currently, the plant produces enriched 


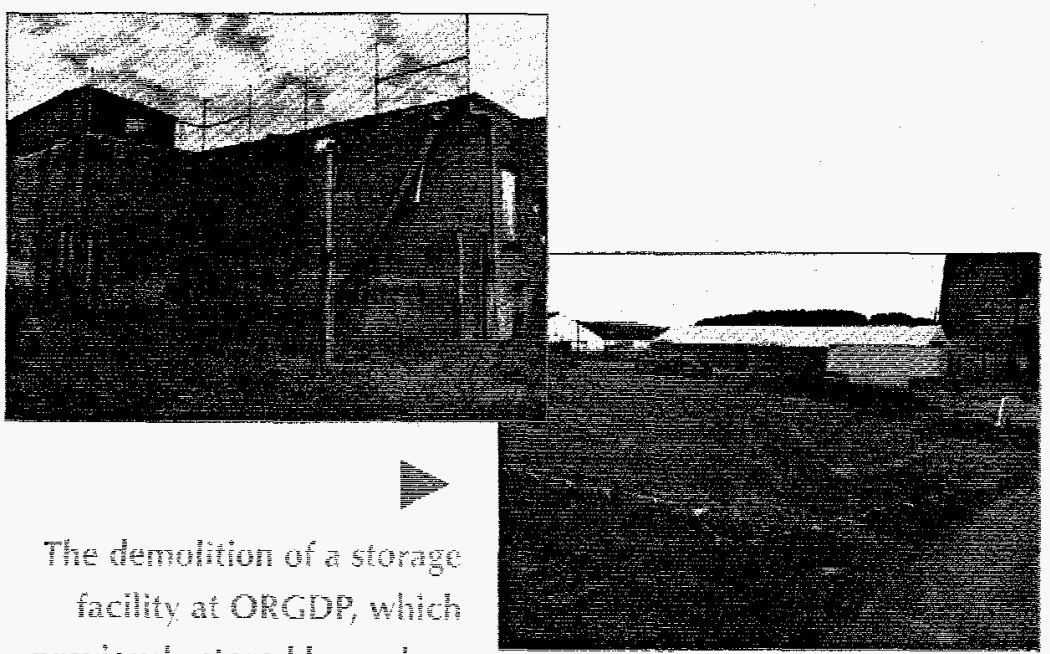

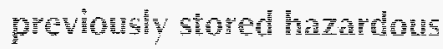

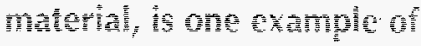

DOP's

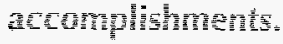

UF6 for use as fuel in commercial nuclear power plants.

The Paducah Gaseous Diffusion Plant is located 10 miles west of Paducah, Kentucky in the southwestern part of the state. The enriched uranium produced by this plant is shipped for further enrichment to Portsmouth.

DOE introduced a number of radioactive and hazardous substances to the GDPs through its enrichment activities: trichloroethylene (TCE), a volatile organic compound commonly used as a solvent; Technetium 99 (Tc-99), a radionuclide; and PCBs, a carcinogenic substance used in electrical equipment. TCE and Tc-99 have been found in the outcome-oriented management practices for its environmental programs. In Fiscal Year 1994, DOE completed 11 D\&D and remedial final actions at the GDPs: three at Oak Ridge, one at Paducah, and seven at Portsmouth. These notable "onthe-ground" D\&D Fund accomplishments involved both decontamination and decommissioning of the facilities and remedial actions to mitigate imminent public and/or worker risk at the sites. In addition, ground water at Paducah, while both TC-99 and PCBs have been found in the surface water and sediments at both Portsmouth and Paducah.

\section{Producing results}

Through its post-Cold War openness with stakeholders and focus on "on-the-ground" achievements, DOE is committed to cost-effective, numerous ongoing cost reduction initiatives are underway to reduce the total cost necessary to complete D\&D of the GDP sites.

One example of how DOE achieved tangible results during Fiscal Year 1994 is the decontamination of over 10,000 transformers and capacitors located at the ORGDP. The project consisted of draining hazardous fluid from the electrical components and preparing them for

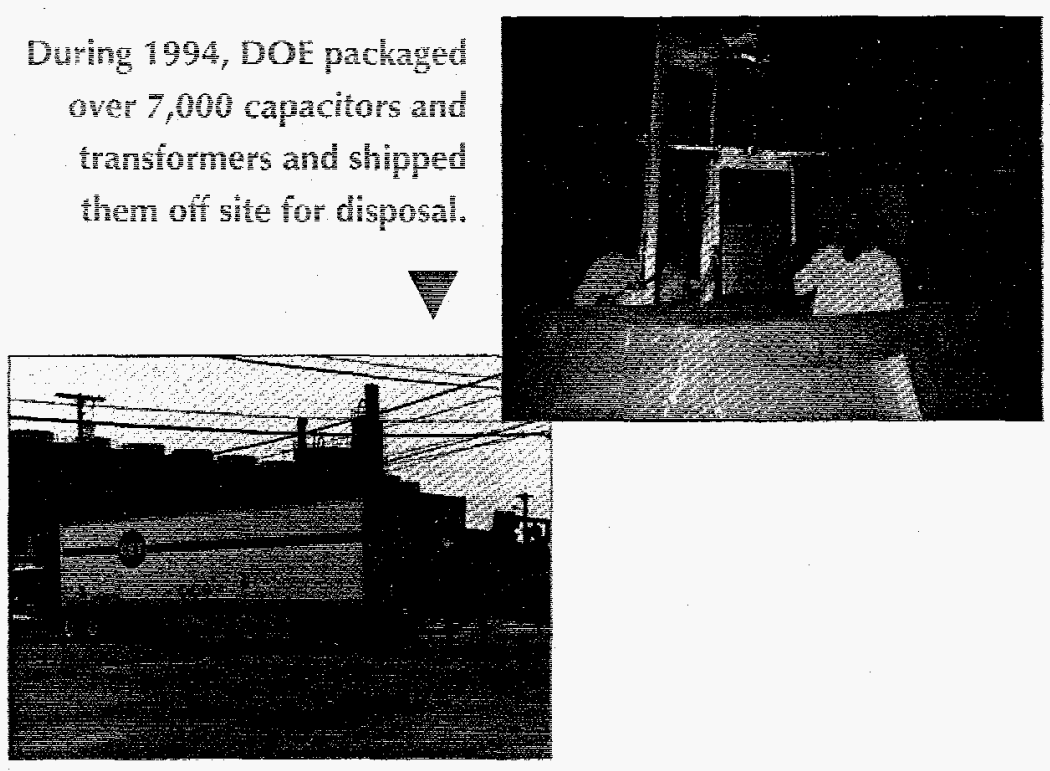




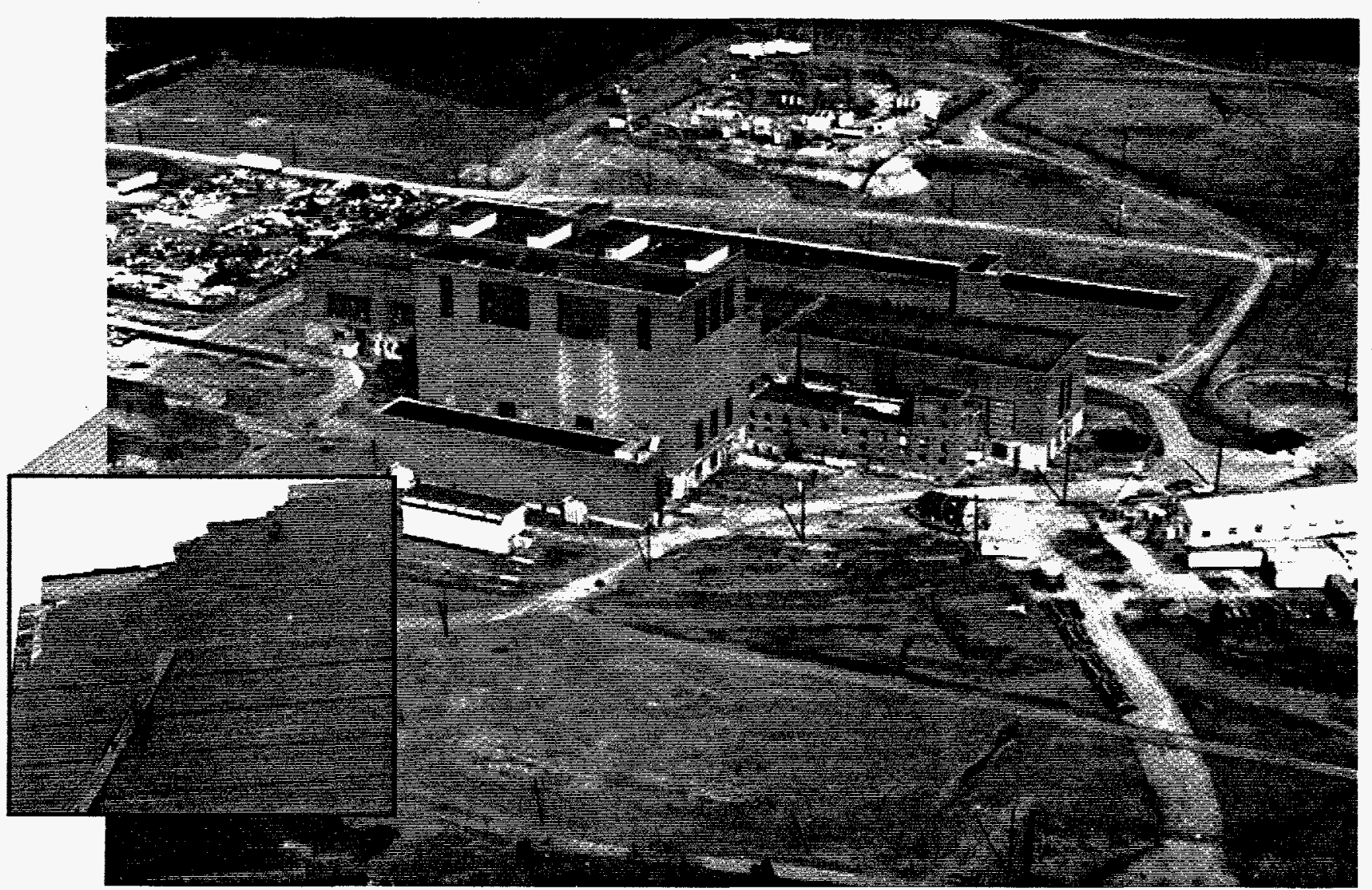

shipment to a licensed, off-site disposal area. DOE shipped 7,000 such components off site in Fiscal Year 1994. The PCBcontaminated fluids were destroyed through incineration.

\section{Exercising management and financial control}

The ORGDP powerhouse supplied the electrical power for the plant beginning in the 1940s and continued to operate until 1962. The facility was then used for various operations including storage and office space. During the late 1980s, DOE determined that there was no further beneficial use for the powerhouse facility. The powerhouse is scheduled for demolition as part of the D\&D Program because of the advanced physical deteriora- tion of the structure. Nearby public rail and river transportation make this location an attractive site for future commercial development, an opportunity already being pursued by local business and industry.

The powerhouse demolition project is serving as a pilot for an innovative, cost reducing contracting strategy. This approach, an initiative that is consistent with the Administration's "Re-inventing Government" theme, has three major parts: 1) breaking up the entire ORGDP D\&D project into discrete tasks, such as the powerhouse demolition; 2) negotiating a fixed-price agreement for the task, utilizing an independent cost estimate; and 3) shifting financial risk to the contractor team, whereby project underruns and overruns

\section{穓}

The dimmolition of the ORGDY powerhouse is a pilot for an imnovative contracing strateg that is projected to save an estimated $\$ 14$ millon. Close-up shows detall of buinding Ineterionation.

are fully shared by the contractors and DOE. The benefits of this approach include cost savings to the Fund, the creation of performance incentives to enhance work performance, and a shifting of liability from the Government to contractors. DOE estimates cost savings to the Government through utilization of this contracting strategy 


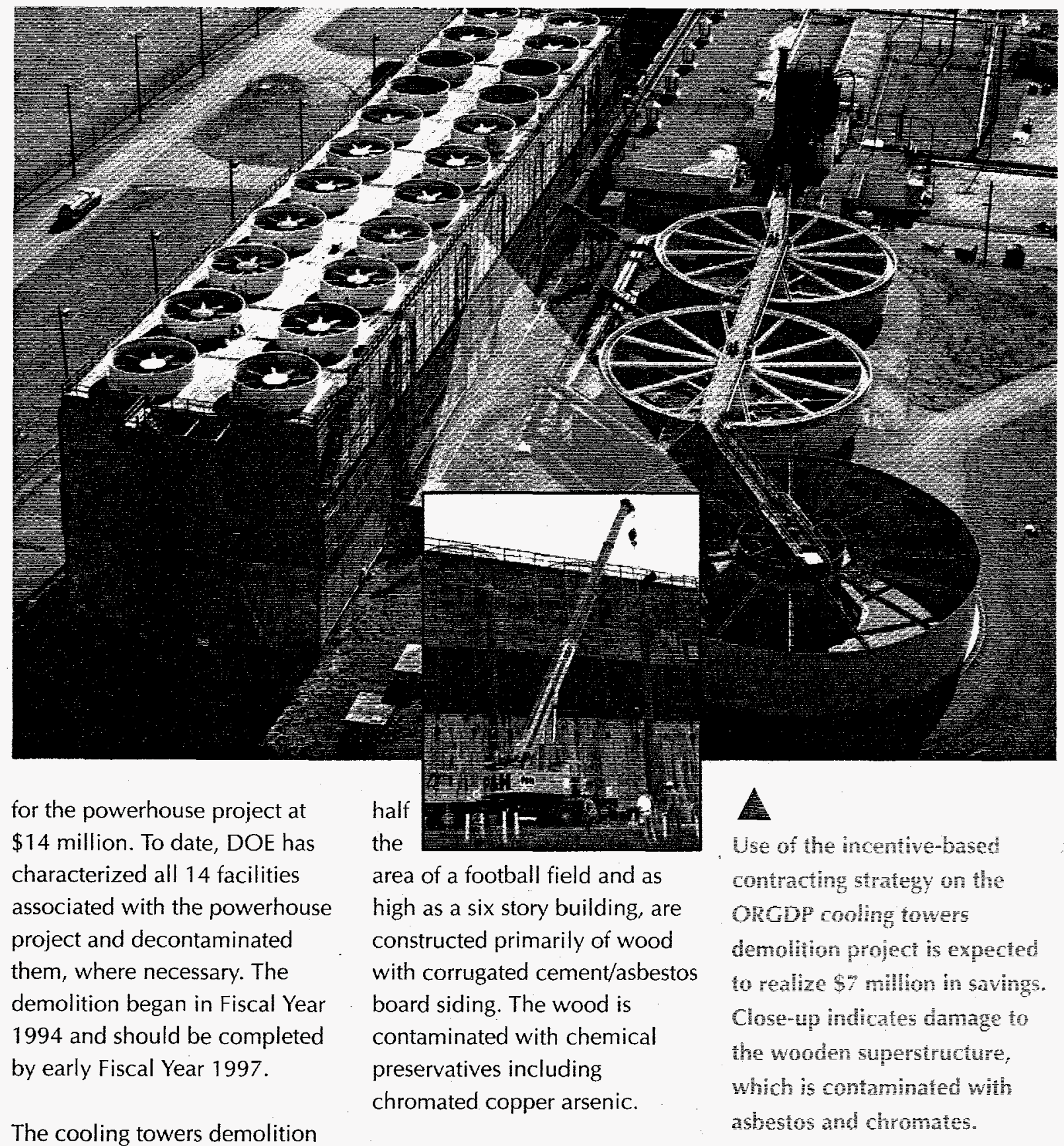

project will involve the demolition of 35 facilities including six cooling towers, six clarifiers, six above ground process-liquid storage tanks, and 17 auxiliary buildings. When operational, the ORGDP required cooling towers to transfer heat from process cooling water to the atmosphere. These superstructures, which are each roughly

Since the shutdown of the ORGDP in 1987, the towers have not been maintained and have begun to deteriorate. Because of the fire hazard in the wooden structures which could release airborne contaminants as well as DOE's emphasis on permanent solutions, all cooling tower facilities will be completely demolished.

Making this project a pilot under the incentive-based contracting strategy is estimated to save the
Government over $\$ 7$ million. DOE completed characterization of the cooling towers superstructures and demolition began in January 1995. 


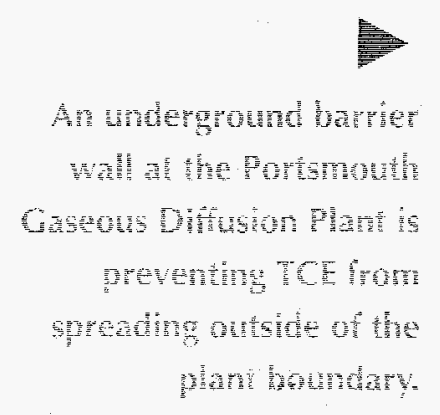

Mitigating urgent risks and maintaining a safe workplace

The Portsmouth Gaseous Diffusion Plant has successfully completed construction of an underground barrier wall at the southern boundary of the site. The wall will prevent migration of TCE outside of the plant boundary to nearby residential wells. DOE used a crane equipped with deep soil mixing equipment to install the threefoot wide wall, which is imbedded at least o feet into the subsurface bedrock layer. The ": was then mixed with a clay n. serial to an average depth of 25 feet. DOE completed the project in only two weeks during September 1994.

The Paducah Gaseous Diffusion Plant site has begun controlling the source of radioactive isotopes, metals, and PCB releases into a drainage ditch, which subsequently migrate into surface water, sediments, and ground water. This "interim measure" includes installation

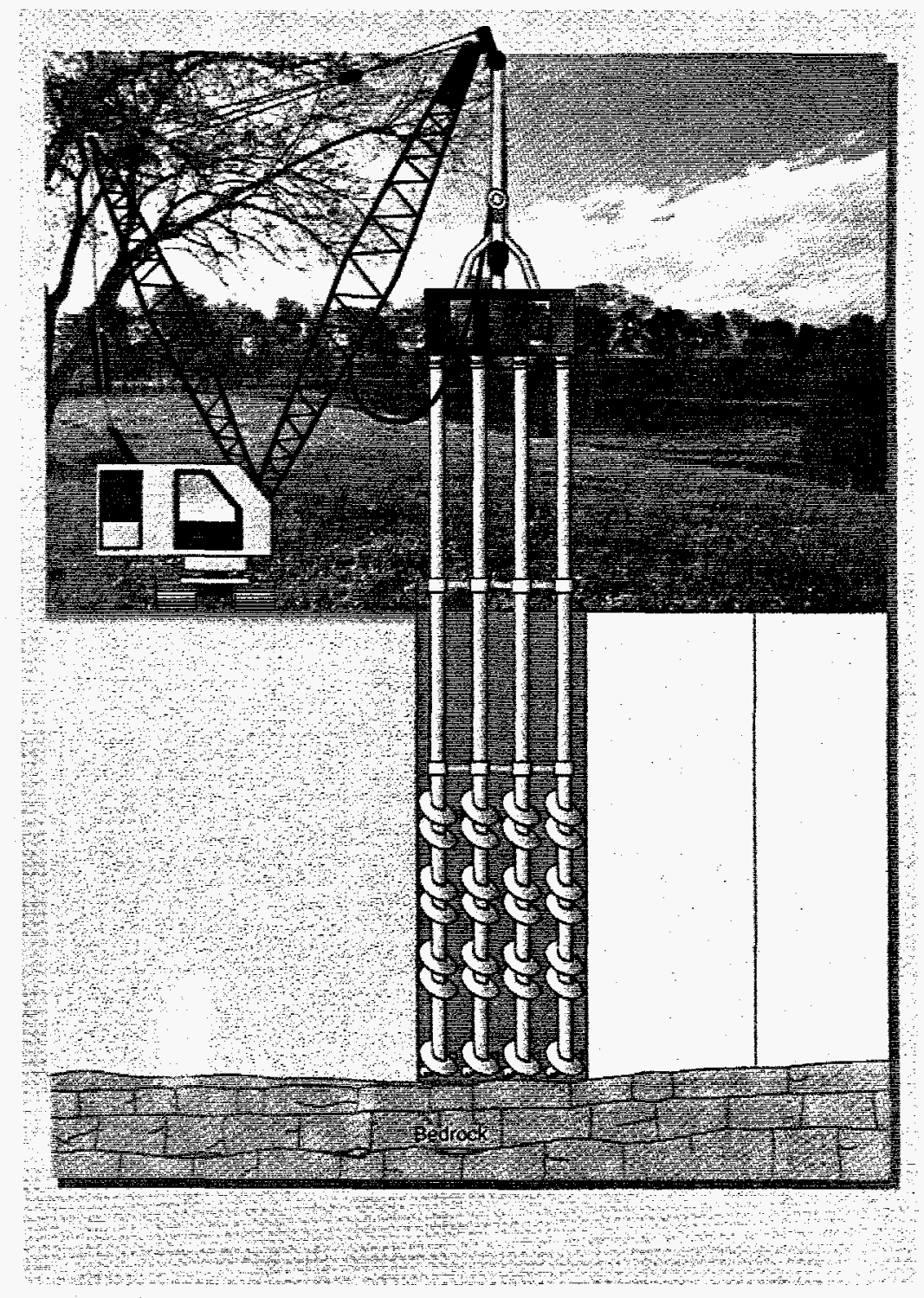

of an ion exchange filtration system, settling lagoons, lift stations, and pipelines. DOE will initiate the final remedial action after surface water contamination sources and relationships are fully understood.

The "Northwest Plume" interim action at Paducah is a first step in controlling the spread of TCE and TC-99 contamination off site. A plume, as shown by the graphic on the next page, is the spread of contaminated ground water. The plume control action consists of installing four ground water extraction wells - two on site at the plume source and two off site at the tip of the highly concentrated plume - to contain existing contamination until the characteristics of the plume movement are more fully understood and a final action can be formulated. DOE will complete construction of this project in the summer of 1995 . 


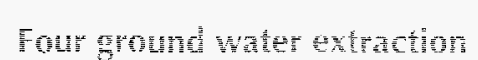

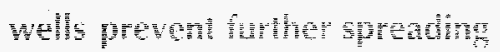
of the Paturte Nonthes"

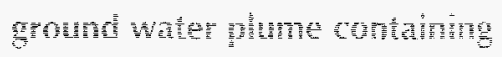
trichormethen (TC) ant Tremethmeas (T)-90).

\section{Utilizing innovative technologies to lower cost}

The challenge at all GDPs is to implement the most cost effective environmental management methods. In Fiscal Year 1994, the Portsmouth GDP completed cleanup of oil-contaminated clay soils using an innovative, in-situ (in-place) treatment. The soils were contaminated with volatile organic compounds (VOCs) from waste oils including TCE and trichloroethane. However, instead of using existing technologies such as capping or excavation, DOE used an in-situ technology after extensive laboratory studies verified its effectiveness.

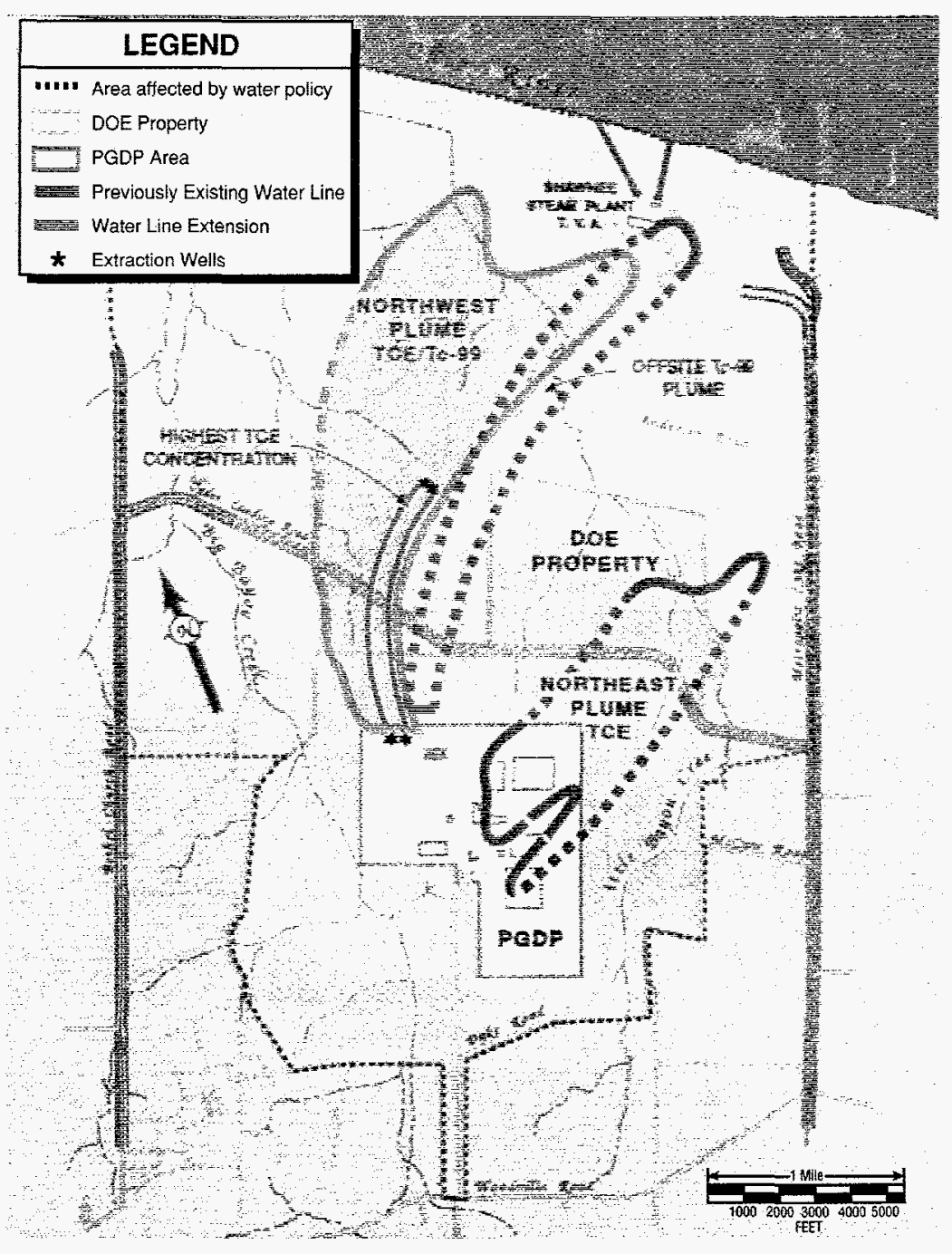

The innovative technology DOE used to remediate the clay soil was an in-situ thermal vapor extraction (TVE) process enhanced by peroxidation destruction. The picture on the next page illustrates the offgas shroud and mixing tool used to implement the technology. The mixing tool is a 10 -foot diameter, dual blade system, with injection ports at the back of each blade.

This innovative technology saved a total of $\$ 83$ million in construction costs. DOE originally estimated the excavation, removal, storage, and treatment of the soils to cost $\$ 89.8$ million, whereas the actual cost of the in-situ TVE was $\$ 6.8$ million. 

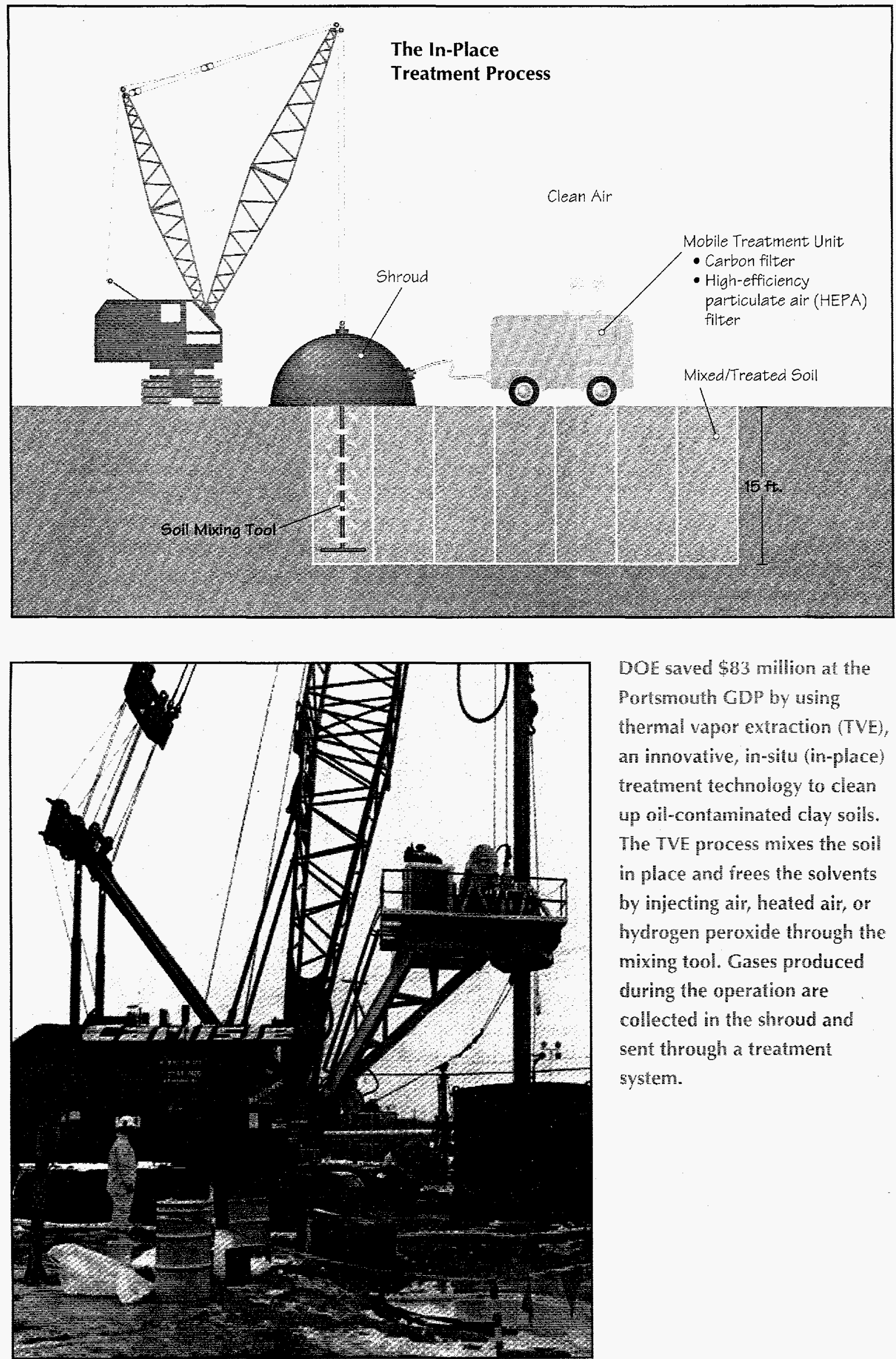

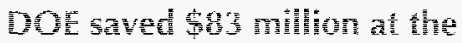

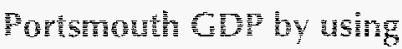

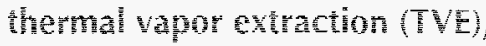
an inovalve, in-silu (in-piace) trechenentechology to chan un oll-contaminated clay solls. The TUE process mixes the soil in piace and treos the solvents by injectng air; healed ait, or hydrogen peroxide through the mixing tool. Gases produced cung the operation are collected in the shroud and

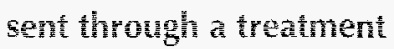
system. 


\section{Reducing the Costs of Decommissioning}

\section{靠}

s of September 30, 1994, the Department estimated the cost for $D \& D$ of the billion (FY 1994 Dollars). DOE initiated several actions to reduce the costs of decommissioning the GDPs. These efforts include: utilization of value engineering (VE) approaches; implementation of recycling programs; resolution of land use and cleanup level issues; and development and use of innovative technologies. In addition, the National Academy of
Sciences (NAS) is conducting a study to identify cost saving measures associated with decommissioning the GDPs.

Value engineering approach to cost and scope of decommissioning

$V E$ is a technique for evaluating a product or process by breaking down the product or process into its discrete functions and examining alternative, less costly means of performing these functions. This

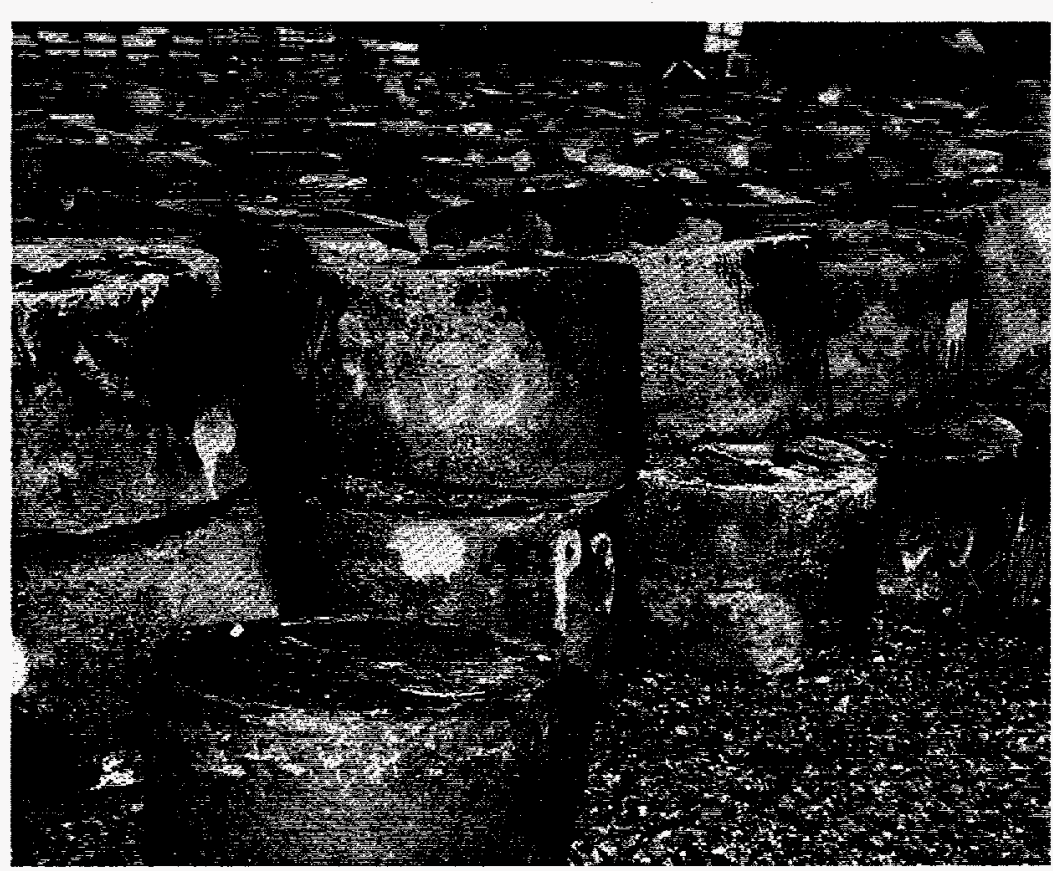

technique has been successfully used to lower costs on projects both in the public and private sectors. DOE has initiated value engineering on the GDP D\&D with the goal of finding ways to reduce the total cost of D\&D. The initial VE sessions examined the assumptions that form the basis for the estimate to determine if they are realistic. The necessity of restrictive assumptions, which tend to increase cost, will be addressed. Through $V E$, the Department hopes to significantly reduce the $D \& D$ financial liability at the GDPs.

\section{Recycling at GDP sites}

The Department intends to maximize the potential for recycling and reusing discarded

The Deparment is investigating the cust and feasibiny of secyciny these ingots and other

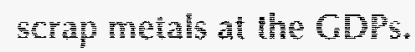




\section{Future Use Decisions Impact D\&D Costs}

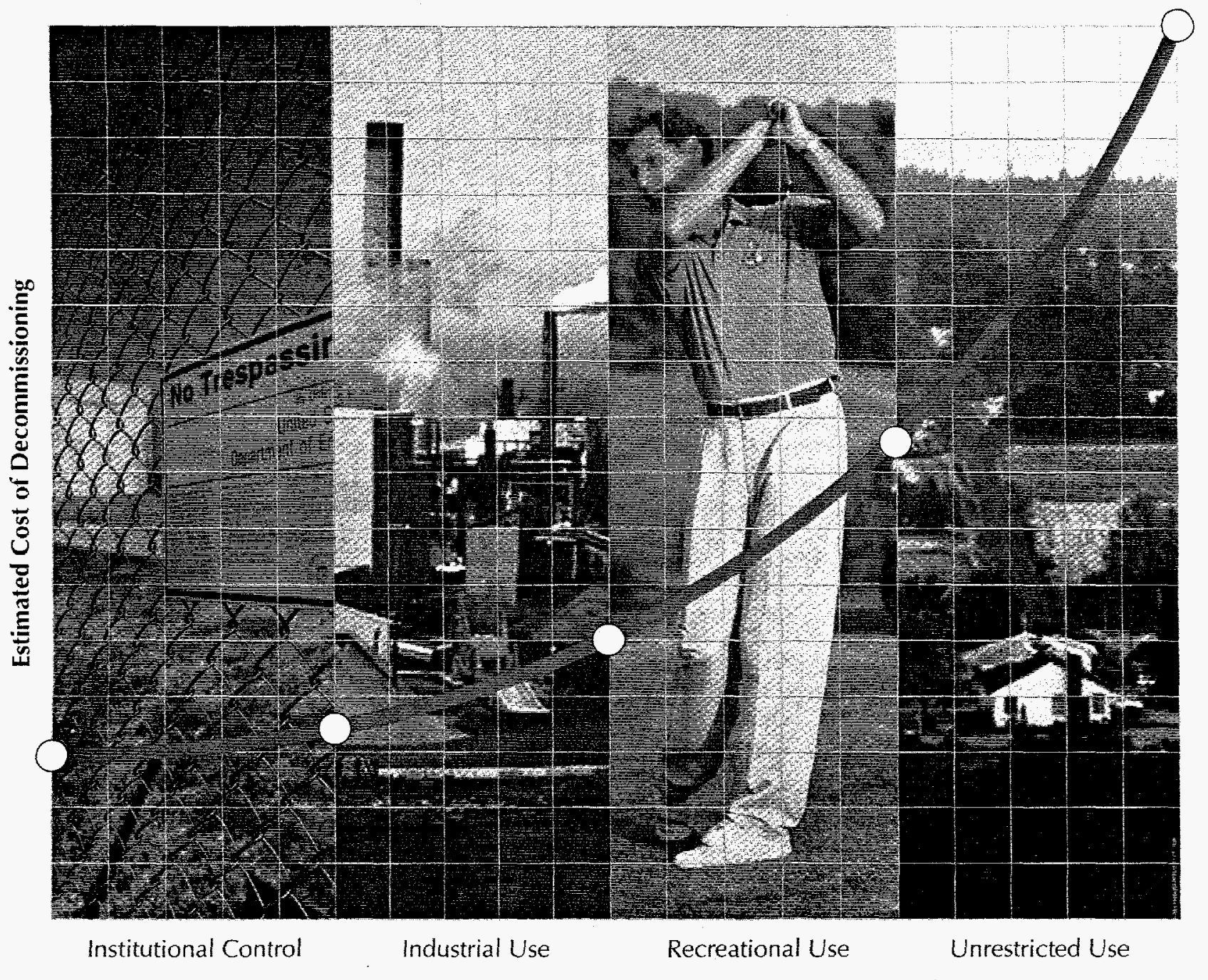

Land Uses

metals and construction materials. Recycling discarded metals and materials may reduce waste disposal costs associated with decommissioning. "Recycle 2000" - a DOE-wide initiative to make waste containers from radioactively contaminated steel - is evaluating the economic benefits of re-using surplus materials rather than disposing of them. Scrap metals at the GDPs are potential candidates for recycling under this program. There is evidence that recycling will reduce the costs of decommissioning the GDP building structures.

\section{Resolution of land use and cleanup level issues}

Commitments to restore site properties to support specific future activities (e.g., industrial use versus residential use) as well as Federal and state criteria for cleanup will have a significant impact on the total costs for decommissioning the GDPs. DOE is obtaining stakeholder
Decisions on future use directy impact the cost of decommissioning the $\mathrm{GDP}_{\mathrm{s}}$ DOE, in consultation with stakeholderc, is analyzing the range of future use options for the GDPs, considering lechnical and legal constraints as well as economic opportunities and public opinion. 
input on expectations for future use of the sites. For example, the Oak Ridge site is utilizing the "Common Ground" process, which seeks public participation through frequent meetings to identify future land use preferences of local residents. Similar efforts are underway at Paducah. In addition, DOE is participating in both national and international efforts to set realistic standards for cleanup levels. Analyzing the cost of cleanup versus the benefit of risk reduction is the foundation of DOE's environmental management efforts.

\section{Development and use of innovative technologies}

Innovative and improved technologies hold great promise for reducing the cost of decommissioning the GDPs. The development of superior technologies can be achieved through DOE technology development programs and coopera- tive arrangements with nonDOE organizations. The Department is partnering with the private sector to develop and use innovative technologies across the complex. The GDPs are participating in this effort. One example is the full scale testing of an in-situ process at Portsmouth that involves the removal of uranium deposits from GDP equipment by using a chemically active gas.

\section{National Academy of Sciences study}

As part of the enabling legislation in the Energy Policy Act of 1992 (Public Law 102-486), the NAS has been commissioned to conduct a study and provide recommendations for reducing costs associated with the decommissioning of the GDPs. A committee of highly qualified personnel from industry, academia, and public interest groups will conduct decision and process analyses, cost/benefit analyses, and technology evaluations. Findings, options, and recommendations derived during the study are scheduled to be released in late calendar year 1995. 


\section{United States Department of Energy Office of Environmental Management Uranium Enrichment Decontamination and Decommissioning Fund}

Financial Statements

September 30, 1994 and 1993 


\title{
KPMG Peat Marwick LP
}

\author{
60 East South Temple
}

Suite 900

Salt Lake City, UT 84111

\section{Independent Auditors' Report on Financial Statements}

Office of Environmental Management

United States Department of Energy:

We have audited the accompanying statements of financial position of the Uranium Enrichment Decontamination and Decommissioning Fund (D\&D Fund, or Fund) as of September 30, 1994 and 1993, and the related statements of operations and changes in net position (deficit) and cash flows for the years then ended. These financial statements are the responsibility of the management of the Uranium Enrichment Decontamination and Decommissioning Fund. Our responsibility is to express an opinion on these financial statements based on our audits.

We conducted our audits in accordance with generally accepted auditing standards; Government Auditing Standards (1988 revision), issued by the Comptroller General of the United States; and Office of Management and Budget (OMB) 3ulletin 93-06, Audit Requirements for Federal Financial Statements. Those standards require that we plan and perform the audit to obtain reasonable assurance about whether the financial statements are free of material misstatement. An audit includes examining, on a test basis, evidence supporting the amounts and disclosures in the financial statements. An audit also includes assessing the accounting principles used and significant estimates made by management, as well as evaluating the overall financial statement presentation. We believe that our audits provide a reasonable basis for our opinion.

As described in note 1 , the financial statements were prepared in conformity with the hierarchy of accounting principles and standards approved by the principals of the Federal Accounting Standards Advisory Board. This hierarchy is a comprehensive basis of accounting other than generally accepted accounting principles.

In our opinion, the financial statements referred to above present fairly, in all material respects, the financial position of the United States Department of Energy's Uranium Enrichment Decontamination and Decommissioning Fund as of September 30, 1994 and 1993, the results of its operations and changes in net position (deficit) and its cash flows for the years then ended on the basis of accounting described in note 1.

As discussed in note 4, the D\&D Fund has recorded a liability of $\$ 17.4$ billion as of September 30,1994 . for the costs of decontaminating and decommissioning (D\&D) the gaseous diffusion facilities in Oak Ridge, Tennessee; Paducah, Kentucky; and Portsmouth, Ohio (Diffusion Facilities). The recorded liability is based on a cost estimate under which the costs of $D \& D$ range from $\$ 11.3$ billion to $\$ 24.2$ billion, with a most likely cost of $\$ 16.1$ billion. The liability has been adjusted for inflation since the estimate was published, but does not include an estimate of the effects of future inflation on D\&D costs. Because the 
completion of D\&D is scheduled to occur in the year 2031, the actual costs may be significantly higher than the recorded liability. In addition, proposed delays, if implemented, in the accomplishment of D\&D may cause costs to increase. The Department of Energy (Department) plans to conduct a value engineering review of the $D \& D$ cost estimate during fiscal year 1995, with the goal of reducing the costs to complete D\&D activities. Changes in technology and in decisions by the Department as to the extent of decontamination required may result in additional cost reductions. The Department is presently unable to determine the impact of the factors discussed above on the liability for decontamination and decommissioning costs.

As discussed in note 6, the Energy Policy Act of 1992 (Act) provides for payment from the D\&D Fund of the annual cost of remedial action at the Diffusion Facilities to the extent the amount available in the D\&D Fund is sufficient. To the extent the amount available in the Fund is insufficient to pay remedial action costs, the Act provides that the Department, not the Fund, will be responsible for such costs. Because the Department may be responsible for remedial action costs, the Fund's recorded liability for remedial action at September 30, 1994 consists only of $\$ 191$ million of future appropriations for remedial action costs that have been signed into law, plus unexpended appropriations of $\$ 73$ million. The D\&D Fund will make additional accruals of remedial action costs if Congress appropriates additional funds for that purpose. The Department is presently unable to determine the amount of additional remedial action costs, if any, that should be recognized in the financial statements.

As discussed in note 9, the Department is presently storing approximately 560,000 metric tons of depleted uranium hexafluoride (UF-6) generated from the operation of the Diffusion Facilities by the Department and its predecessor agencies. The Department estimates that, as of September 30, 1994, its share of the cost of depleted UF- 6 disposition would be $\$ 1.3$ billion, including adjustments for inflation since September 1991. However, the extent to which the Department's stockpile of depleted UF-6 will require disposal is dependent on future restrictions on the use of this material for military purposes and on other alternative uses. The Department is presently unable to determine what portion of the stockpile will require disposal. Accordingly, no provision for the cost of depleted UF-6 disposal is included in the accompanying financial statements.

\section{KPMG Peat Maureck UP}

December 15, 1994 


\section{Uranium Enrichment Decontamination and Decommissioning Fund}

Statements of Financial Position

September 30, 1994 and 1993

(in thousands)

Intragovernmental:

Cash

Cash equivalents

$\$$

4,148

29,119

52,653

118,896

Cash and cash equivalents (note 2)

56,801

148,015

U.S. Treasury securities, net (notes 2 and 3 )

247,154

Accrued interest receivable

2,350

Other current receivables

1,168

Governmental:

Assessments receivable from domestic utilities (note 8):

Current

Long-term

Total assets

The accompanying notes are an integral part of these statements. 


\section{Uranium Enrichment Decontamination and Decommissioning Fund}

\section{Statements of Financial Position}

September 30, 1994 and 1993

(in thousands)

Governmental:

Liabilities covered by budgetary resources:

Decontamination and decommissioning (note 4)

Uranium and thorium licensee claims (note 5)

Remedial action (note 6)

Other accrued expenses

Total funded liabilities

Liabilities not covered by budgetary resources:

Decontamination and decommissioning (note 4)

Uranium and thorium licensee claims (note 5)

Remedial action (note 6)

Total unfunded liabilities

Total liabilities
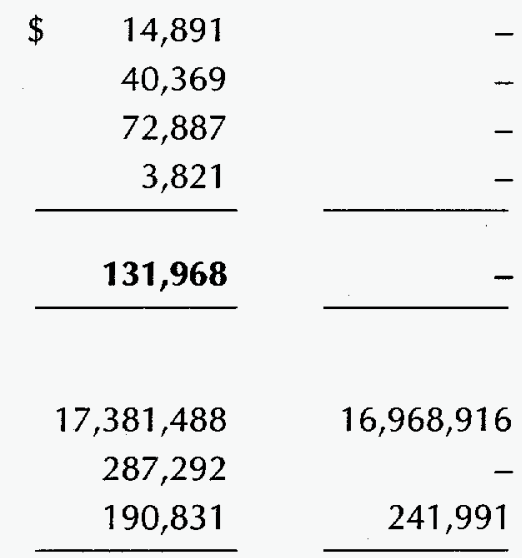

$17,859,611 \quad 17,210,907$

$17,991,579 \quad 17,210,907$

Net position (deficit):

Balances:

Unexpended appropriations with U. S. Treasury:

Unobligated

Obligated

Cumulative results of operations

Future funding requirements

Total net position (deficit)

$(15,670,863)$

$(14,911,983)$

Commitments and contingencies (notes $4,5,6,7,9$, and 10)

Total liabilities and net position (deficit)

$\$ 2,320,716$

$2,298,924$

The accompanying notes are an integral part of these statements. 


\section{Uranium Enrichment Decontamination and Decommissioning Fund \\ Statements of Operations and Changes in Net Position (Deficit)}

For the year ended September 30, 1994 and the period from October 24, 1992 to September 30, 1993

(in thousands)

Revenues and financing sources:

Appropriations (note 7):

Transfer from uranium enrichment

Defense environmental restoration and waste management Assessments against domestic utilities (note 8)

Interest income

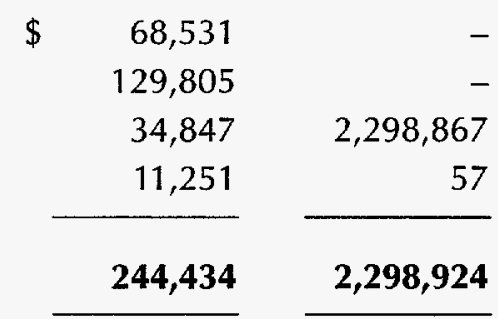

Expenses and financing uses:

Decontamination and decommissioning (note 4)

Uranium and thorium licensee claims (note 5)

Remedial action (note 6)

\section{Total revenues and financing sources}

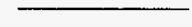

\section{Total expenses and financing uses}

Excess of expenses and financing uses over revenues and financing sources 


\section{Uranium Enrichment Decontamination and Decommissioning Fund}

Statements of Cash Flows

For the year ended September 30, 1994 and the period from October 24, 1992 to September 30, 1993

(in thousands)

Cash flows from operating activities:

Excess of expenses and financing uses over revenues and financing sources

Adjustments to reconcile excess of expenses and financing uses over revenues and financing sources to net cash provided by operating activities:

Net amortization and accretion of premiums and discounts

on U.S. Treasury securities

Loss on sale of U.S. Treasury securities

(Increase) decrease in operating assets:

Assessments receivable from domestic utilities

$\$(758,880)$

$(14,911,983)$

Accrued interest receivable

37,666

$(2,150,909)$

Other current receivables

Increase in operating liabilities:

Decontamination and decommissioning

427,463

$16,968,916$

Uranium and thorium licensee claims

327,661

21,727

Remedial action

3,821

Net cash provided by operating activities

149,213

148,015

Cash flows from investing activities:

Purchases of U.S. Treasury securities

Proceeds from maturities of U.S. Treasury securities

Proceeds from sale of U.S. Treasury securities

Net cash used in investing activities

Net increase (decrease) in cash and cash equivalents

Cash and cash equivalents, beginning of year

$(807,126)$

550,500

16,199

$(240,427)$

$(91,214)$

148,015

148,015

Cash and cash equivalents, end of year

$\$ \quad 56,801$

148,015 


\title{
Uranium Enrichment Decontamination and Decommissioning Fund
}

\author{
Notes to Financial Statements
}

September 30, 1994 and 1993

(1) Basis of Presentation, Description of Reporting Entity, and Summary of Significant Accounting Policies

\section{(a) Basis of Presentation}

These financial statements have been prepared to report the financial position and results of operations of the Uranium Enrichment Decontamination and Decommissioning Fund (D\&D Fund, or Fund), as required by the Chief Financial Officers Act of 1990. The statements have been prepared from the books and records of the Fund in accordance with the applicable form and content requirements of Office of Management and Budget (OMB) Bulletin 94-01 and the Fund's accounting policies, which are summarized in this note. These statements are therefore different from the financial reports, also prepared for the Fund pursuant to OMB directives, that are used to monitor and control the Fund's use of budgetary resources.

The U.S. Department of Energy's (Department's) headquarters, field offices, and the management and operating contractors conducting environmental restoration activities at the Department's facilities discussed in note (1)(b), record D\&D Fund activity in their accounting systems. The management and operating contractors integrate their accounting systems with the Department through the use of reciprocal accounts. All management and operating contractors are required under provisions of their respective contracts to maintain a separate set of accounts and records for recording and reporting Fund financial transactions in accordance with the Department's accounting practices and procedures. These financial statements are prepared by extracting and adjusting Fund-related data from the financial records of the Department and its contractors.

\section{3) Reporting Entity}

The Energy Policy Act of 1992 (Energy Policy Act, or Act) transferred the uranium enrichment business to the United States Enrichment Corporation as of July 1, 1993. However, the Act requires the Department to retain ownership and responsibility for the costs of environmental cleanup resulting from the government's operation of the three gaseous diffusion facilities located in Oak Ridge, Tennessee; Paducah, Kentucky; and Portsmouth, Ohio (Diffusion Facilities) prior to that date.

The Act established the D\&D Fund within the U.S. Treasury as of October 24, 1992, to pay for the costs of decontaminating and decommissioning the Diffusion Facilities (note 4). The Act further provides that the Fund will reimburse licensees operating uranium or thorium processing sites for the costs of environmental cleanup at those sites, subject to a maximum reimbursement limit (note. 5). The Act also provides for payment of the costs of remedial action at the Diffusion Facilities, to the extent that the amount available in the Fund is sufficient (note 6). To pay for these activities, the Act authorizes revenues of $\$ \mathbf{4 8 0}$ million per year, adjusted annually for inflation, over a fifteen-year period. The revenues will be obtained from government appropriations and from assessments against domestic utilities. 


\title{
Uranium Enrichment Decontamination \\ and Decommissioning Fund
}

\author{
Notes to Financial Statements
}

(c) Basis of Accounting

The D\&D Fund uses the accrual method of accounting. The accrual method of accounting requires recognition of the financial effects of transactions, events, and circumstances in the periods when those transactions, events and circumstances occur, regardless of when cash is received or paid. The Fund also uses budgetary accounting to facilitate compliance with legal constraints and to keep track of its budget authority at the various stages of execution, including allotment, obligation, and eventual outlay.

The financial statements are prepared in accordance with the following hierarchy which constitutes a comprehensive basis of accounting:

Individual standards agreed to and published by the Joint Financial Management Improvement Program Principals, based upon recommendations from the Federal Accounting Standards Advisory Board.

Form and content requirements included in OMB Bulletin 94-01, Form and Content of Agency Financial Statements.

Accounting standards contained in agency accounting policy, procedures manuals, and/or related guidance as of March 29, 1991, so long as they are prevalent practices.

Accounting principles published by authoritative standard setting bodies and other authoritative sources (1) in the absence of other guidance in the first three parts of this hierarchy, and (2) if the use of such accounting standards improves the meaningfulness of the financial statements.

\section{(d) Cash Equivalents}

Cash equivalents of $\$ 52.7$ million at September 30, 1994 and $\$ 118.9$ million at September 30 , 1993, consist of overnight investments with the U.S. Treasury. For purposes of the statements of cash flows, the D\&D Fund considers all Treasury securities with initial maturities of ninety days or less to be cash equivalents.

\section{(e) U.S. Treasury Securities}

The Energy Policy Act requires the investment of the D\&D Fund's balance with the U.S. Treasury in obligations of the United States. 


\title{
Uranium Enrichment Decontamination and Decommissioning Fund
}

\author{
Notes to Financial Statements
}

(e) U.S. Treasury Securities (continued)

The D\&D Fund classifies its investments in Treasury securities in one of two categories: availablefor-sale or held-to-maturity. Held-to-maturity securities are those securities which the Fund has the ability and intent to hold until maturity. All other securities are classified as available-for-sale.

Available-for-sale securities are recorded at fair value. Unrealized holding gains or losses on available-for-sale securities are excluded from earnings and are reported as a separate component of net position until realized. Held-to-maturity securities are recorded at amortized cost, adjusted for the amortization or accretion of premiums or discounts. Premiums and discounts are amortized or accreted over the life of the related security as an adjustment to yield using the effective interest method. Realized gains and losses for securities classified as available-for-sale are included in earnings and are derived using the specific identification method for determining the cost of securities sold. All securities sold prior to maturity are redeemed by the U.S. Treasury at fair value on the date of sale.

\section{(f) Plant and Equipment}

Plant and equipment acquired by the D\&D Fund are charged to operations when purchased, unless the plant or equipment will be used for purposes other than environmental cleanup. All plant and equipment held by the D\&D Fund at September 30, 1994 are used in environmental cleanup activities.

\section{(g) Revenue Recognition}

Revenue from assessments against domestic utilities is recognized when such assessments are authorized by legislation. Revenue recognized includes known adjustments for transfers between utilities and other reconciliation adjustments. Increases or decreases in current and future assessments due to changes in the Consumer Price Index for All Urban Consumers (Consumer Price Index), as published by the Department of Labor, are recognized in each fiscal year as such changes occur.

Revenue from government appropriations is recognized at the later of the beginning of each fiscal year, when appropriations may be apportioned to the Department by the Office of Management and Budget, or the date the appropriations legislation is signed into law.

\section{(h) General and Administrative Expenses}

Salaries, benefits, and related costs of Department personnel involved in the management and oversight of the resources in the D\&D Fund are funded under separate appropriations, and are not included in the accompanying financial statements. 


\section{Uranium Enrichment Decontamination and Decommissioning Fund}

\section{Notes to Financial Statements}

(2) Cash and Cash Equivalents

Cash and cash equivalents consist of the following funds with the U.S. Treasury (in thousands):

\begin{tabular}{|c|c|c|c|}
\hline & & 1994 & 1993 \\
\hline Restricted & $\$$ & 172,913 & 148,015 \\
\hline Accrued but not paid & & 131,968 & - \\
\hline Due from another appropriation & & $(1,168)$ & - \\
\hline Obligated appropriations & & 233 & - \\
\hline Unobligated appropriations & & 9 & - \\
\hline Total fund balance with Treasury & & 303,955 & 148,015 \\
\hline Less U.S. Treasury securities & & 247,154 & - \\
\hline Cash and cash equivalents & $\$$ & 56,801 & 148,015 \\
\hline
\end{tabular}

(3) U.S. Treasury Securities

All Treasury securities held at September 30,1994 are classified as held-to-maturity and all are due within one year. The market value of Treasury securities held by the D\&D Fund was $\$ 246.7$ million at September 30, 1994.

During fiscal year 1994, a security with an amortized cost (in thousands) of $\$ 16,200$ was transferred from held-to-maturity to available-for-sale to obtain cash for operations. Proceeds from the sale of this security were $\$ 16,199$ and the gross realized loss was $\$ 1$.

(4) Decontamination and Decommissioning

In fiscal year 1993, the D\&D Fund recorded a provision of $\$ 17.0$ billion for the cost of decontaminating and decommissioning the Diffusion Facilities. The provision is based on an estimate prepared for the Department and published in September 1991. The estimated costs of decontamination and decommissioning range from $\$ 11.3$ billion to $\$ 24.2$ billion, with a most likely cost of $\$ 16.1$ billion. The estimate is based on the Department's plan to remove all contaminated equipment from the facilities and to decontaminate all surfaces in each structure before decommissioning. The work is scheduled to begin in the year 2002 and continue through 2031. The estimate also includes costs of surveillance and maintenance prior to the decontamination and decommissioning. 


\title{
Uranium Enrichment Decontamination and Decommissioning Fund
}

\author{
Notes to Financial Statements
}

(4) Decontamination and Decommissioning (continued)

Since the estimate did not include adjustments for anticipated inflation, the provision recorded in fiscal year 1993 includes adjustments for estimated cost increases from September 1991 through September 1993, based on the change in the Consumer Price Index. The statement of operations for fiscal year 1994 includes a provision of $\$ 483.5$ million for the increase in estimated cost during the year. Changes in the liability for decontamination and decommissioning from October 24, 1992 to September 30, 1993 and during the year ended September 30, 1994 may be summarized as follows (in thousands):

Balance, October 24, 1992

Provision for decontamination and decommissioning costs

Balance, September 30, 1993

Decontamination and decommissioning costs incurred

Provision for estimated cost increases

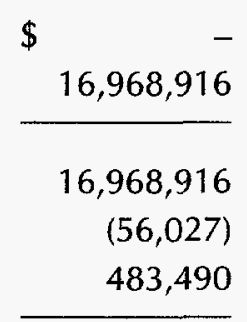

$\$ 17,396,379$

Of the total liability of $\$ 17.396$ billion for decontamination and decommissioning as of September $30,1994, \$ 15$ million is covered by budgetary resources and $\$ 17.381$ billion is not covered by budgetary resources.

Because the estimate on which the recorded liability for decontamination and decommissioning costs is based does not include an estimate of the impact of inflation on such costs, the actual costs may be significantly higher than the recorded liability. In addition, proposed delays, if implemented, in the accomplishment of decontamination and decommissioning may cause costs to increase. The Department plans to conduct a value engineering review of the decontamination and decommissioning cost estimate during fiscal year 1995, with the goal of reducing the costs to complete decontamination and decommissioning activities at the Diffusion Facilities. Changes in technology and in decisions by the Department as to the extent of decontamination required may result in additional cost reductions. The Department is presently unable to determine the impact of the factors discussed above on the liability for decontamination and decommissioning costs. 


\title{
Uranium Enrichment Decontamination and Decommissioning Fund
}

\author{
Notes to Financial Statements
}

\section{(5) Uranium and Thorium Licensee Claims}

The Energy Policy Act provides that the D\&D Fund will reimburse licensees operating uranium or thorium processing sites for the costs of environmental cleanup at those sites, subject to maximum reimbursements of $\$ 270$ million for uranium licensees and $\$ 40$ million for the thorium licensee, plus adjustments for inflation. In fiscal year 1994, the Department published a final rule governing reimbursement for such costs and began receiving claims for reimbursement.

Claims for reimbursement amounted to $\$ 127.8$ million from uranium and thorium licensees as of September 30, 1994. Based on claims received and anticipated future claims, the D\&D Fund has recorded a provision of $\$ 327.7$ million for reimbursement of such claims in the statement of operations for fiscal year 1994. The provision consists of the maximum reimbursement limits established by the Energy Policy Act, plus adjustments for inflation through September 30, 1994. Of the total liability of $\$ 327.7$ million for uranium and thorium licensee claims as of September 30 , $1994, \$ 40.4$ million is covered by budgetary resources and $\$ 287.3$ million is not covered by budgetary resources.

\section{(6) Remedial Action}

The Energy Policy Act provides that the annual cost of remedial action at the Diffusion Facilities will be paid from the Fund to the extent the amount available in the D\&D Fund is sufficient. To the extent the amount in the Fund is insufficient to pay remedial action costs, the Act provides that the Department will be responsible for such costs.

At September 30, 1994 and 1993, the Fund recorded liabilities of $\$ 263.7$ million and $\$ 242.0$ million, respectively, for remedial action costs. Of the total liability of $\$ 263.7$ million for remedial action as of September $30,1994, \$ 72.9$ million is covered by budgetary resources and $\$ 190.8$ million is not covered by budgetary resources. Because the Act places primary responsibility for remedial action costs with the Department if sufficient resources are not available in the D\&D Fund, the Fund's recorded liability for remedial action at the end of each fiscal year includes only the funding for such costs provided by Congress in the D\&D Fund appropriation for the succeeding fiscal year, plus the unexpended portion of such appropriations for current and previous fiscal years. The D\&D Fund will make additional accruals of remedial action costs if Congress appropriates funds for that purpose. The Department is presently unable to determine the amount of additional remedial action cost, if any, that should be recognized in the Fund's financial statements. 


\title{
Uranium Enrichment Decontamination and Decommissioning Fund
}

\author{
Notes to Financial Statements
}

(6) Remedial Action (continued)

An estimate of the total cost of remedial action at the Diffusion Facilities was prepared for the Department in fiscal year 1991. The estimate includes costs of all phases of environmental restoration, including monitoring for three years following remediation. The estimated total cost of $\$ 3$ billion does not include an estimate of the impact of inflation on the cost of the work, which is scheduled to be completed by the year 2010. Because the estimate does not include an estimate of the impact of inflation on remedial action costs, the actual costs may be significantly higher than the estimate. In addition, proposed delays, if implemented, in the accomplishment of remedial action may cause costs to increase. Changes in technology and in decisions by the Department and regulatory authorities as to the extent of remedial action required may result in cost reductions. The Department is presently unable to determine the impact of the factors discussed above on estimated remedial action costs.

\section{(7) Government Appropriations}

The Energy Policy Act authorizes annual government appropriations to the D\&D Fund through fiscal year 2007, equal to the difference between $\$ 480$ million, adjusted annually for increases in the Consumer Price Index, and the assessment against domestic utilities. For fiscal years 1994 and 1993, actual appropriations have not equaled the amounts authorized by the Act. During fiscal year 1994, the Fund received appropriation transfers of $\$ 68.5$ million from uranium enrichment and a payment of $\$ 129.8$ million from defense environmental restoration and waste management, for a total of $\$ 198.3$ million in appropriations revenue. The Fund received no appropriations during fiscal year 1993. The following is a summary of government appropriations authorized but not received by the D\&D Fund, excluding adjustments for inflation, as of September 30, 1994 (in millions):

\begin{tabular}{|c|c|c|c|}
\hline $\begin{array}{c}\text { Year ended } \\
\text { September } 30\end{array}$ & $\begin{array}{l}\text { Appropriations } \\
\text { authorized }\end{array}$ & $\begin{array}{l}\text { Appropriations } \\
\text { received }\end{array}$ & $\begin{array}{l}\text { Authorized, } \\
\text { not received }\end{array}$ \\
\hline 1993 & $\$ 330.0$ & - & 330.0 \\
\hline \multirow[t]{2}{*}{1994} & 331.5 & 198.3 & 133.2 \\
\hline & $\$ 661.5$ & 198.3 & 463.2 \\
\hline
\end{tabular}

Government appropriations of \$133.7 million have been approved for fiscal year 1995 . 


\title{
Uranium Enrichment Decontamination and Decommissioning Fund
}

\author{
Notes to Financial Statements
}

(8) Assessments Against Domestic Utilities

The Energy Policy Act authorizes assessments by the D\&D Fund against domestic utilities who purchased uranium enrichment services from the Department and its predecessor agencies prior to the Act. The assessments are based on the ratio of such services purchased by domestic utilities to total services provided to domestic and foreign utilities and to the government. The assessments are limited to $\$ 150$ million each year by the Act; and will continue through fiscal year 2007 or until $\$ 2.25$ billion, exclusive of indexing adjustments, has been collected. The amount of the assessments will be adjusted each year based on changes in the Consumer Price Index.

During fiscal year 1994, the Fund recognized revenue of $\$ 34.8$ million from reconciliation adjustments and the increase in the 1994 and future assessments against domestic utilities resulting from the increase in the Consumer Price Index during the fiscal year. In fiscal year 1993, the Fund recognized $\$ 2.3$ billion of revenue, representing the entire fifteen-year series of assessments against the utilities, plus adjustments for the increase in the Consumer Price Index through September 1993. Management believes all current and future assessments against domestic utilities are collectible.

\section{Disposition of Depleted Uranium Hexafluoride}

The gaseous diffusion process of uranium enrichment produces two streams of uranium hexafluoride (UF-6) - one that has an increased concentration of the uranium isotope U-235 (enriched) and one that has a reduced level of U-235 (depleted). Enriched UF-6 is converted into enriched uranium, used by utilities to generate electricity and by the government for military purposes. The Department is presently storing approximately 560,000 metric tons of depleted UF-6, containing about 380,000 metric tons of depleted uranium, generated from the operation of the Diffusion Facilities by the Department and its predecessor agencies.

The Energy Policy Act restricts the use of depleted UF-6 to military purposes until October 1998. The Department is preparing to assess strategies for long-term management of the depleted uranium hexafluoride stockpile, including potential alternative uses, and plans to issue a draft environmental impact statement in fiscal year 1998. The ultimate uses of the depleted UF- 6 and the need for disposal will be evaluated during the process of preparing the draft environmental impact statement.

In fiscal year 1991, a contractor for the Department conducted a study on the ultimate disposition of this material. The study assumed that there would be approximately 620,000 metric tons of depleted uranium, including 240,000 metric tons generated by the United States Enrichment Corporation, in storage by the end of fiscal year 2005. The study estimated that the costs of disposition of depleted UF-6 will range from $\$ 1.3$ billion to $\$ 4.1$ billion, with a probable cost of $\$ 1.9$ billion, excluding adjustments for inflation after September 1991. 


\title{
Uranium Enrichment Decontamination and Decommissioning Fund
}

\author{
Notes to Financial Statements
}

(9) Disposition of Depleted Uranium Hexafluoride (continued)

Costs of disposition of depleted UF- 6 generated by the United States Enrichment Corporation will be the Corporation's responsibility. The Department estimates that, as of September 30, 1994, its share of the cost of depleted UF- 6 disposition would be $\$ 1.3$ billion, including adjustments for inflation since September 1991. However, the extent to which the Department's stockpile of depleted UF-6 will require disposal is dependent on future restrictions of the use of this material for military purposes and on other alternative uses. The Department is presently unable to determine what portion of the stockpile will require disposal. Accordingly, no provision for the cost of depleted UF-6 disposal is included in the accompanying financial statements.

(10) Litigation

Four appeals have been filed by domestic utilities, arising from the implementation of the rules governing the assessments authorized by the Energy Policy Act. Management and the Department's legal counsel cannot predict the outcome of the appeals; however, management believes that valid defenses exist against the claims and will vigorously contest them.

Various other legal actions are pending or may be asserted in the future against the D\&D Fund arising out of the Department's activities at the Diffusion Facilities. Such actions include claims and disputes asserted by domestic utilities with respect to assessments by the Fund, contract claims and disputes, workers' compensation claims, and environmental issues. Some of the foregoing matters involve or may involve contract termination and validity claims and citizen action claims, which could be significant if the original claims were granted. Although the ultimate liabilities with respect to these matters cannot be ascertained, management, after providing for certain known claims, believes that any resulting liability should not materially affect the financial position of the D\&D Fund as of September 30, 1994. 